\title{
STRUCTURES IN THE NOVEL OF BIDADARI-BIDADARI SURGA BY KARYA TERE LIYE ( STRUCTURALISM ANALYSIS)
}

\author{
Nurul Azizah, Siti Gomo Attas, Herlina \\ Pascasarjana Pendidikan Bahasa, Universitas Negeri Jakarta \\ Jl. Rawamangun Muka, Jakarta Timur 13220 \\ Email : nurulfanza94@gmail.com
}

\begin{abstract}
This study aims to describe the character and characterization, plot, background, style of language, the point of view, theme and the mandate of Tere Liye's novel of Bidadari-Bidadari Surga. The method in this study is the content analysis of qualitative approach. Based on data analysis, the following results are summarized as follows: 1) The main character in Tere Liye's Novel of Bidadari-Bidadari Surga is Laisa, additional characters are Mamak, Babak, Dalimunte, Ikanuri, Wibisana, Yashinta. 2) The mixed flow, covering the situation Mother send Message to his children about the condition of the sickly Laisa, her mother sent to her children who message to he who received the first Message that Dalimunte, Ikanuri, Wibisana, and Yashintaberanjak adult, childhood continue to haunt them, climax that is Kak Laisa not yet married must pass by Dalimunte and his siblings. Dalimunte finally married after being forced by Kak Laisa. 3) The background consists of three sections, a backdrop of thirty-one backgrounds, a twenty-seven background setting, and a social setting that is a disgrace in the Lahambay Valley if an unmarried girl over the age of twenty. 4) The Language Style is the style of comparison, contradiction, and affirmation. 5) The third person's perspective "he" is omniscient and the point of view of "I" extra figure 6) The theme is the sincere sacrifice of a brother for the future of his younger brothers. 7) The mandate of this life must be lived with sincerity and full of gratitude for all that God has given.
\end{abstract}

Keywords: Structure, Intrinsic Element, Novel

\section{INTRODUCTION}

According to Wellek and Warren (1995: 3), literature is a creative activity of art. Literature is a creative activity of art that expresses the human personality in the form of experiences, thoughts, feelings, ideas, spirit, beliefs by describing the state and social life of society, as well as the values mandated by the creator through the characters of the story in a form of concrete

BAHTERA : Jurnal Pendidikan Bahasa dan Sastra, Volume Juli 2018 
images to create the interesting with language tools.

The novel is one of the literary formed by two elements, namely intrinsic and extrinsic elements. The intrinsic element is an element that builds an internal literary work internally. This intrinsic element consists of characters and characterizations, plot, background, style of language, the point of view, theme and mandate While the extrinsic element is an element that is outside the text of literary that affect the text itself. This extrinsic element consists of psychology, sociology, philosophy, and biography of the author.

The reason the author examines the novel as the object of research because a novel always contain valuable experience that can inspire and motivate the reader. Novels are the most popular literary form in the world. This form of literature is most widely circulated, because of its broad communications power in society. A novel is a form of literature in which there are cultural values, social, moral and educational.

This novel Telling about the struggle of a brother who has four younger siblings, with an unyielding struggle to educate and raise his four younger siblings to become a successful where at that time Laisa have economic limitations, with a sincere Laisa cease schools in order to help her mother to make money so that his siblings do not stop school and can become successful people in the future. Besides that many other trials that befall Laisa as he preceded by his siblings in terms of marriage, but Laisa remains sincere in living the life that is most important for Laisa is happiness brothers and her mother. This novel teaches us sacrifices, selflessness, hard work and always loving family.

This study specializes in intrinsic elements. The reason the author examines the intrinsic element of a novel because the intrinsic element is the elements that build the literary itself. The intrinsic element of a novel is an element that directly participates in building the story. The intricacies of these intrinsic elements make the novel tangible. Conversely, when viewed from the point of viewers, the elements of this story will be found if you read a novel. The intrinsic elements referred to in a literary work are figures and characterizations, plots, backgrounds, 
language styles, points of view, themes and messages.

\section{THEORETICAL REVIEW}

The novel is a prose-shaped story in large measure. The vast size here can mean stories with complex plots, numerous characters, complex themes, diverse story situations, and various story settings (Sumardjo and Saini 1997: 29). A work of fiction is manifested because it is structured by conjuring up various elements, such as intrinsic and extrinsic elements of fiction. The organization of the various literary elements into a whole and reflects the interesting and meaningful personality of literary works is called the fictional structure (Zulfahnur et al, 1996: 24).

According to Nurgiyantoro (2010: 165), the character of the story is the person displayed in a work of narrative or drama which the reader is interpreted to have a certain morality and tendency expressed in speech and what is done in action. According to Aminuddin (2002: 79), events in fiction as well as events in everyday life, always depicted by certain figures or perpetrators.
According to Sumardjo and Saini (1997: 139), the plot is a series of stories from beginning to end which is a series of events that one with the other connected with causality. That is, the first event causes the second event to occur, the second event results in an event. third, and so further so that basically the last event by the first event.

According to Abrams in Nurgiantoro (2010: 216), the setting refers to the sense of place, the relationship of time, and the social environment in which the events are told. The setting or setting, also known as the fulcrum, refers to the sense of place, the relationship of time, and the social environment in which the events are told. Setting in fiction is not just a background, it means not just showing where the incident happened and when. A short story or novel must indeed be somewhere and at a time. There must be places and spaces (Sumardjo and Saini, 1997: 75).

Language style is the way in which the author exposes ideas according to the goals he wants to achieve. According to Aminuddin (2002: 72), in the literary style, the term contains an understanding of the way an author conveys his ideas by using 
beautiful and harmonious language media and able to create meaning and atmosphere that can touch the intellectual and emotional power of the reader.

The point of view is essentially a strategy, technique, strategy, which the author deliberately chooses to propose the idea of his story. The point of view can be equated meaning and can even clarify with the term center of separation (Nurgiyantoro, 2010: 248).

According to Nurgiyantoro (2010: 68), the theme is the basis for the development of the whole story, so it is animating all parts of the story, while according to Aminuddin (2002: 91), the theme is the idea underlying a story so that the role as the author base describes the work of fiction creation .

The message is a message of ideas, ideas, moral teachings, and human values that the author wishes to convey through the story (Zulfahnur et al, 1996: 26). The message is the message or idea the author wishes to convey to the reader as outlined in his work (Kamus Istilah Sastra dalam Supratman, 1996: 541).
Structuralism is essentially a way of thinking about the world that is primarily concerned with the responses and descriptions of structures. In this view, literature is assumed to be a phenomenon that has structures related to one another (Endraswara, 2003: 49). Meanwhile, according to Faruk (2012: 173), structuralism is an understanding, a belief, that everything that exists in this world has structure, work structurally.

\section{RESEARCH METHOD}

This research uses content analysis by using a qualitative approach. The qualitative content analysis method is used to describe characterization, plot, background, language style, the point of view, theme and address in Tere Liye's novel of the Angel of Bidadari-Bidadari Surga. To analyze the intrinsic elements of the novel, the novel structuralism study was studied based on the intrinsic structure of the characterization, flow, setting, language style, the point of view, theme, and message of Tere Liye's novel of the Bidadari-Bidadari Surga. The study of structuralism is used to describe and explain the intrinsic elements present in the 
novel. The instrument of data used in this research is researcher own with assisted work table based on sub-focus of research that is: 1) description of character and characterization in novel Bidadari-Bidadari Surga by Tere Liye. 2) Descriptions of the flow in Tere Liye's novel of BidadariBidadari Surga. 3) background description in Tere Liye's novel of the BidadariBidadari Surga. 4) The description of the style of language in Tere Liye's novel of the Bidadari-Bidari Surga. 5) Descriptive point of view in Tere Liye's novel of the Bidadari-Bidadari Surga. 6) The description of the theme in Tere Liye's novel of the Bidadari-Bidadari Surga. 7) Descriptions of the message in Tere Liye's novel Bidadari-Bidadari Surga.

\section{RESULT AND DISCUSSION}

Discussion of the research findings is tailored to the focus and sub-focus of the study, then interpreted or verified findings obtained by linking existing theories. The discussion of this research is based on the research focus of the Novel BidadariBidadari Surga by Tere Liye Structure a. Descriptions of Characters

1. Laisa

Laisa is the girl who has the willingness to sacrifice this is visible from the words spoken by his mother that is the dialogue quoted from the novel Bidadari-Bidadari Surga..

"One drop of tears was finally dripping from a dim-faced woman lying helplessly on the bed. They both looked at each other. Fifteen seconds passed. Only the valley wind blasted the shutters. Oh God, really since childhood he kept everything alone. Really. For the sake of their younger siblings for their better lives. he was willing to do it. But, it looks like it's all over. The time is over, not for long. "(Page, 2).

Laisa is also the figure of a hardworking woman, loving family, and never give up visible from the following dialogue quote.

"Although he has knowledge of how to plant strawberries, although taking care of hundreds of polybags is not an easy job. Eight months passed, the strawberry garden was a total failure. Half the stem died by the rainy season, submerged. Half of its fruits rotten when taken to the township district 
to be brought to the provincial city ". (p. 177).

"Mamak let Laisa-plant their fields with strawberries, this time allowing the whole to be planted. "Learn from mistakes, Mak. Laisa knows what to do now. "(Page 183).

"Laisa is right, Laisa learns a lot from her mistakes. Four months passed, after days of sun baking while preparing new polybags, putting manure into poly bags. the rainy season that once flooded the polybag, the good news finally arrived. Four hundred strawberry trees flourish from black plastic bags. Unbelievable. Four months passed again the days spent with hard work, Laisa painstaking care for the one-by-one trunk. Spent his entire life into the one-hectare garden. And Mamak finally smiled broadly, ripe red fruits began to appear from the trunks. " (p. 184).

2. Mamak
The figure of a parent who is very patient, caring and loving children as seen in the excerpt of this novel below.

"Lais, do you see Ikanuri and Wibisana? Mamak asked quietly.

"Ee, is not it there, mak?" She turned her forehead swab, took off the palm fronds, steaming steam from the big ricecookers chest, pointed to a group of tough boys who were making pipes. "No lais", "ee, was there, mak ...". really naughty! Wherever they go. "What do you need to look for, mak?". Mamak think fast, later after Dzuhur if not visible too, you look for them ". (pp. 100-101).

\section{Babak}

Babak or father is a father figure who is responsible to the family and love his wife he died attacked Tiger.

"Mamak married a second time with the youth of the village. Act them now. Young people who once very broken hearts to see Mamak married to others. now regain his latent love. A round can accept Mamak as it is, a poor widow. Also can accept the little Laisa ". 


\section{Dalimunte}

Dalimunte is an intelligent, diligent child, proved to be 12 years old. Dali has made a waterwheel that can be used for the sake of villages in the Lahambay valley, one of which is to drain water into the irrigated fields of the villagers in the Lahambay valley.

"His legs trembled slightly with a sizable millwheel for a twelve-year-old boy. The rushing water of the river made it more difficult to tread, carefully mounted on a bamboo beam. The boy breathed a sigh of relief. He just fixed his position. Finally, a windmill was installed. He stepped aside from the river. Smiles happily to see his work. The mill begins to move slowly with the flow of water and the empty bamboo that is made in such a way begins to spin, drain the river water upwards. Spilled on arrival at the highest screen. Success! The little boy was wide-eyed. " (p. 58).

"Actually ... actually, Dali also does not like school. Really, Dalimunte said hoarsely. She blew her nose. Of the five brothers, Dalimunte is the most easily touched, "brother knows, Dali even prefers to work in the garden to help Mamak, help brother. Dali does not like school. So sister does not have to be sad ... ". (p. 179)

"Dali can learn from anywhere. Borrow books. Not necessarily school. Dali does not have to make big brother-"

"Dali not want to school. Dali does not want to make sister Lais sad. Do not want to see Mamak hard work baked the sun. Dali does not want a school ". (p. 179)

\section{Ikanuri and Wibisana}

Ikanuri and Wibisana are the naughty children, stolen, brave dared to challenge her sister, hard to hide her feelings and stubborn. But in the end, they become good children.

"IKANURI! WIBISANA! just like a radio that is suddenly tuned fast. Laisa exclaimed fiercely. Running and approaching. WHAT ARE YOU DOING HERE?"

"Ergh, ee, we're checking the uncle Burnan mango tree, right?" "Ikanuri replied quickly, typical of Ikanuri, potluck, with a totally innocent face. Wibisana the same 
stupid, participate nodded "Yes, Sister. We again count the fruit there how many ". (p. 105)

\section{LET US GO HOME!}

"Puncture tip limb is getting tighter. The grimace winced, but he still did not leave alone. "BACK TO HOME NOW!". DO NOT WANT! "Ikanuri somehow what was in the head, suddenly shouted no less tightly. Brushed the tip of the end of the branch on his chest. "DO NOT WANT!" The Ikanuri glared. (107).

We do not want to go home. Do not want. You're not our sister, why do we have to do it !. (p. 107).

\section{Yashinta}

Yashinta has an impatient character, great curiosity, caring, loving nature, smart and crying, obedient and stubborn.

"A month ago when Laisa helped Mamak collect damar far in the middle of the forest, Laisa accidentally found dam made beaver. Amazingly there are five beavers swimming. Very funny to see it. Although then Laisa really regrets to tell what he saw to Yashinta, especially by adding it to the sentence: very funny to see it. Telling it to Yashinta is tantamount to inviting trouble. So endless every night Yashinta sulk want to go there. Tugging at Laisa's clothes. (p. 42)

\section{b. Plot}

The plot used in the novel BidadariBidadari Surga by Tere Liye is a mixed groove. Very interesting, especially when there is a conflict between Ikanuri and Wibisana, Dalimunte's intelligence and hard head Yashinta. But Laisa, as a good sister, never let them down. Even when fighting three tigers in the jungle for the sake of Ikanuri and Wibisana, Laisa did not flinch one bit. Then another groove contained in the novel that is divided into five parts, covering the situation that is when Mamak send a message to her children who contain about the condition of the sickness of Laisa getting worse. Generating circumstances, namely when Dalimunte, Ikanuri, Wibisana, and Yashinta are on their way home to the Lahambay Valley. Rising action is when Laisa, Dalimunte, Ikanuri, Wibisana, and Yashinta grow up, childhood also continues to haunt them, one after the other. 
Climax (climax stage) is when the unmarried Laisa must be passed by Dalimunte and his siblings. The denouement is when Dalimunte finally wants to marry Cie Hui.

\section{c. Background}

The background is divided into three sections, namely the background of the place (Valley, strawberry plantation, large room, Rome Airport, Semeru mountain peak, Middle forest, Lahambay valley, riverside, city of Rome, subdistrict town, kampong hall, stilt house, Switzerland, Airport city, under mango tree, Forest of the jungle, Mount Kendeng, Upper Village, Paris International Airport, Edge of the field, Multi-purpose building of provincial city university, Strawberry Garden, America, Graduation Room, Europe, Singapore International Airport, Kuala Lumpur , Kaimana Islands, Papua, Hospitals, District cities). Timeframe (twenty-five years ago, a month ago, last week, eight years ago, hundreds of years ago, seventy years, ten years ago, six years ago, next week, eight months went by, next year, four months gone by, one year passed, twenty years ago, three years passed, seven years passed, six months went by, six months later, eighteen years ago, fifteen years, five years ago, an hour went by, a year, three days later, two days ago, a week, five minutes later). The social background of the livelihoods of the Lahambay Valley, which on average livelihoods as peasants and side jobs looking for what is in the forest for sale, very low education (rarely they go to grade six), it is a disgrace if a girl unmarried at the age of over twenty, the taboo thing in the Lahambay Valley is that a sister should not marry before her older sister gets married.

\section{d. Language Style}

Language Style, composed of comparative language style: metaphor, simile, personification, hyperbole, antonomasia, metonymic, pars pro toto; language style of contradiction: paradox, antithesis; detachment style: pleonasm.

\section{e. Point of View}

The point of view used is the third person's point of view "he" omniscient and 
the point of view of "I" additional character.

d. Theme

The result of theme analysis in Tere Liye's Novel Bidadari-Bidadari Surga is a sincere sacrifice of a brother for a better future for his younger siblings.

\section{e. Message}

a. Any desire for a better life will come true by working hard.

b. In looking for a life partner, it is not the physical beauty that is the main criterion. Physical beauty is ranked fourth. The most important is the sincere sacrifice, hard work, unyielding attitude, sincerity accepts the limitations that exist on ourselves, affection, and appreciate each other.

c. Should not complain about circumstances that are not as expected. Accept with sincerity and always prejudiced both of what has been determined by God. d. In educating children to do good things, should be a good example. The child will imitate the example in front of his eyes without being forced.

e. Unmarried women up to the age of thirty or more because of physical limitations and always be grateful, do good, and like to share, rest assured in the afterlife will be the celestial nymphs.

\section{CONCLUSION}

Based on the formulation of the problem, there are conclusions obtained by researchers in accordance with the findings. 1) The main character in the novel Bidadari-Bidadan Heaven by Tere Liye is Laisa, while additional characters are Mamak, Babak, Dalimunte, Ikanuri, Wibisana, Yashinta, Wak Burhan, Cie Hui, Wulan, Jasmine, and Goughsky. 2) The flow in Tere Liye's novel BidadariBidadari Surga is a mixed path because the author starts the story with a situation and ends with a solution. 3) The background is the background of the place which includes 31 backgrounds, the background time and 27 background and social background that 
would be a disgrace if an unmarried girl at the age of twenty. 4) The language style of Tere Liye's novel Tere Liye paradise consists of comparative style: metaphor, simile, personification, hyperbole, antonomasia, metonymic, pars pro toto; language style of contradiction: paradox, antithesis; detachment style: pleonasm. 5) The point of view the author uses in Tere Liye's novel Bidadari-Bidadari Surga is the third person's perspective he is omniscient and the point of view of "I" additional characters. 6) The theme of Tere Liye's novel Bidadari-Bidadari Heaven is a sincere sacrifice of a brother for a better future for his younger brothers. 7) First Any desire for a better life will come true by working hard. Second In looking for a life partner is not a physical beauty that is the main criteria. Physical beauty is ranked fourth. The most important is the sincere sacrifice, hard work, unyielding attitude, sincerity accepts the limitations that exist on ourselves, affection, and appreciate each other. third Not to complain about circumstances that do not match expectations.

Accept with sincerity and always prejudiced both of what has been determined by God. Fourth In educating children to do good things, should be a good example. The child will imitate the example in front of his eyes without being forced. The five women who are not married until the age of thirty or more because of physical limitations and always grateful, do good and like to share, rest assured in the afterlife will be the angels of heaven.

\section{REFERENCES}

Aminuddin. 2002. Pengantar Apresiasi Karya Sastra. Bandung: Sinar Bara.

Liye, Tere. 2010. Bidadari-Bidadari Surga. Jakarta: Republika.

Moleong, Lexy J. 2002. Metodologi Penelitian Kualitatif. Bandung: Rosda.

Nurgiyantoro, Burhan. 2010. Teori Pengkajian Fiksi. Yogyakarta: University Gajah Mada Press.

Sumarjo, Jacob dan dan Saini K.M. 1991. Apresiasi Kesusastraan. Jakarta: Gramedia.

Wellek, Rene dan Austin Warren. 1995. Teori Kesusastraan. Jakarta: Gramedia Pustaka Utama. 
BAHTERA: Jurnal Pendidikan Bahasa dan Sastra, Volume 17 Nomor 2 Juli 2018 http://journal.unj.ac.id/unj/index.php/bahtera/

P-ISSN : 0853-2710

E-ISSN : 2540-8968

Zaidan dkk, 2007. Kamus Istilah Sastra.

Jakarta: Balai Pustaka.

Zulfahnur Z. F, dkk. 1996. Teori Sastra, Jakarta: Departemen Pendidikan dan Kebudayaan. 